前号から, 副編集委員長を仰せつかりました藤田直子 (秋田県立大) と申します。これまで英文誌 (JAG) のマ ネージングエディターを 4 年ほど仰せつかっておりまし た。いずれにしても, 経験の少ない私が担当していいもの やら，と戸惑いましたが，これまでは大変お世話になって きたので, 今度は少しでも学会誌の扮役にたてればと思 い，お引き受けしました。着任以来，皆さんから寄せられ た原稿や依頼原稿に目を通すことが以前とは比べ物になら
ないくらい増えたわけですが，自分にとってはなじみのな かった分野にも接することができ，新鮮な気持ちで取り組 んでおります。今回で和文誌としても 5 年目に突入したわ けですが，読者の方々の扮役にたてるような記事の揭載に なるように，心がけたいと思っておりますので，今後とも よろしくお願いいたします。

(副編集委員長 藤田 直子)

複写される方へ

本誌に掲載された著作物を複写したい方は，公益社団法人日本複製権センターと包括複 製許諾契約を締結されている企業の方でない限り，著作権者から複製権等の行使の委託を 受けている次の団体から許諾を受けてください。なお，著作物の転載・翻訳のような，複 写以外の許諾は, 直接本会へご連絡ください。

テ107-0052 東京都港区赤坂 9-6-41 乃木坂ビル

一般社団法人 学術著作権協会（Tel. 03-3475-5618, Fax. 03-3475-5619,

E-mail: info@jaacc.jp)

\title{
Notice about photocopying
}

In order to photocopy any work from this publication, you or your organization must obtain permission from the following organization which has been delegated for copyright clearance by the copyright owner of this publication.

〈Except in the USA〉

Japan Academic Association for Copyright Clearance, Inc. (JAACC)

6-41 Akasaka 9-chome, Minato-ku, Tokyo 107-0052, Japan

Tel. +81-3-3475-5618 Fax. +81-3-3475-5619 E-mail: info@jaacc.jp

〈In the USA 〉

Copyright Clearance Center, Inc.

222 Rosewood Drive, Danvers, MA 01923, USA

Tel. + 1-978-750-8400 Fax. + 1-978-646-8600

\section{日本応用糖質科学会誌「応用糖質科学」 第 5 巻 第 1 号（通巻 17 号）}

\section{平成 27 年 2 月 20 日 印刷 発行}

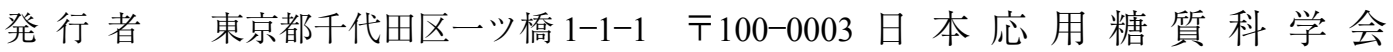
パレスサイドビル

株式会社＼cjkstart毎日学術フォーラム内

発行 所 東京都千代田区一ツ橋 1-1-1 $\bar{\top}$ 100-0003 日 本応用糖質科学会 パレスサイドビル

株式会社 毎日学術フォーラム内

製 作 東京都文京区弥生 2-4-16 †113-0032 一般財団法人 学会誌刊行センター

印刷 所 東京都文京区小石川 1-3-7 ₹112-0002 勝 美 印 刷 株 式 会 社 